\title{
New Data on Trichodinid Ectoparasites (Ciliophora: Peritrichida) of Mullus barbatus ponticus (Mullidae) in the Black Sea
}

\author{
Türkay ÖZTÜRK ${ }^{1, *}$ [D, Ali YEŞiL ${ }^{1,2}$ (]) \\ ${ }^{1}$ Faculty of Fisheries and Aquatic Sciences, Sinop University, Sinop, Turkey \\ ${ }^{2}$ Graduate School of Natural and Applied Sciences, Sinop University, Sinop, Turkey \\ *Correspondence: turkay.ozturk@gmail.com
}

\begin{abstract}
Received 26 March 2019; Accepted 21 May 2019; Release date 15 December 2019.
How to Cite: Öztürk, T., \& Yeşil, A. (2019) New data on trichodinid ectoparasites (Ciliophora: Peritrichida) of Mullus barbatus ponticus (Mullidae) in the Black Sea. Acta Aquatica Turcica, 15(4), 418-424 https://doi.org/10.22392/actaquatr.545083
\end{abstract}

\begin{abstract}
The red mullet, Mullus barbatus ponticus Essipov, 1927 inhabiting the Black Sea was examined for presence of trichodinid ectoparasites. A total of three species of trichodinids belonging to Trichodina and Paratrichodina genera, were identified: Trichodina domerguei Wallengren, 1897, T. ovonucleata Raabe, 1958 and Paratrichodina obliqua Lom 1963. Photomicrographs and morphometric data were presented for each species. The existence of trichodinid parasites in relation to size and the sex of the red mullet as well as their seasonal occurrences were also investigated and determined. This paper is the first report on the trichodinid ectoparasites on the red mullet in Turkey. Trichodina ovonucleata and P. obliqua are new records for Turkish fish parasite fauna, while P. obliqua and T. domerguei are new parasite records for M. barbatus ponticus. The number of hosts of these trichodinid species is increased based on the results of this study in addition to the previously published data.
\end{abstract}

Keywords: Trichodina, Paratrichodina, ectoparasite, red mullet, Black Sea

Karadeniz'deki Mullus barbatus ponticus (Mullidae) balığının Trichodinid Ektoparazitleri (Ciliophora: Peritrichida) Ile Ilgili Yeni Veriler

Özet

Karadeniz'de bulunan barbunya, Mullus barbatus ponticus, balığ1 trichodinid ektoparazitlerin varlığ açısından incelendi. Trichodina ve Paratrichodina cinslerine ait toplam üç trichodinid türü tanımlandı: Trichodina domerguei Wallengren, 1897, T. ovonucleata Raabe, 1958 ve Paratrichodina obliqua Lom 1963. Trichodinid parazitlerin barbunya balığının cinsiyet ve büyüklüğünün yanı sıra mevsimsel bulunuşları da araştırılmış ve belirlenmiştir. Bu makale, Türkiye'deki barbunya balığının trichodinid ektoparazitleri hakkında ilk rapordur. Paratrichodina obliqua ve T. domerguei, $M$. barbatus ponticus için yeni parazit kayıtları iken, $T$. ovonucleata ve $P$. obliqua, Türkiye parazit faunası için yeni kayıtlardır. Bu çalışmanın sonuçlarına göre, bu trichodinid türlerinin konak sayısı, daha önce yayınlanmış verilere ek olarak artmıştır.

Anahtar Kelimeler: Trichodina, Paratrichodina, ektoparazit, barbunya balı̆̆1, Karadeniz

\section{INTRODUCTION}

The family Mullidae Rafinesque, 1815 known as red mullets or goatfishes are widely distributed in many areas of the world and some of their species are economically important. In the Black Sea,the genus Mullus Linnaeus, 1758 is represented by two species, M. barbatus Linnaeus, 1758 and M.surmuletus Linnaeus, 1758 (Ivanova et al., 2014). In addition to these two species, M. barbatus ponticus Essipov, 1927, a subspecies of M. barbatus which lives only in the Black Sea, has also been reported among members of this genus (Hureau et al., 1986; Turan, 2006). However, the taxonomic status of M. barbatus ponticus as a subspecies has not been proven by a molecular and karyological database (Keskin and Can, 2009; Vasileva, 2012). 
The validity of Mullus barbatus ponticus is uncertain. Mullus barbatus is characterized by having a very steep (almost vertical) snout, relatively short barbels that are no longer than pectoral fins, presence of three suborbital scales, short head (approximately 20\% of total length), and the absence of spots and stripes on the body and fins. Whereas, M. barbatus ponticus is characterized by having a curved head and presence of four suborbital scales. It can be distinguished from M. barbatus by maxilla which is reaching beyond anterior eye margin in adults and having only three suborbital scales. The red mullet has a high commercial value and is the main target species of many demersal fisheries operating in the Black Sea, and annual catch was 1406 tonnes in 2017 according to "Turkish Statistical Institute" (TÜIKK, 2018) in Turkey.

The red mullet is not only one of the most consumed fish but also a bio indicator species utilizing to evaluate the biological effects of chemical pollutants in marine organism (Mathieu et al., 1991; Benedicto et al., 2005). Despite their economic and ecological importance in aquatic ecosystems, the number of studies on the ecto-and endo parasites of the red mullet is limited. Trichodinids are commonly found as ectoparasites or ectocommensals on aquatic invertebrates and vertebrates. They are one of the largest groups of ectoparasites in marine and freshwater fish (Lom and Dykova, 1992). Four genera of the family Trichodinidae Claus, 1951, that is, Trichodina Ehrenberg, 1830, Dipartiella Stein, 1961, Trichodinella Srámek-Husek, 1953 and Paratrichodina Lom, 1963, were found to occur on marine fishes (Xu et al., 2002). To our knowledge, about 400 valid species of trichodinids have been reported from both freshwater and marine environments in the world (Wang et al., 2017). Many studies have been conducted on helminth parasite fauna of M. barbatus (Essafi et al., 1983; Ovcharenko and Yurahno, 2006; Carreras-Aubets et al., 2012; Debenedetti et al., 2013; Öztürk and Yeşil, 2018). However, studies on the trichodinid parasites of red mullet are limited (Raabe, 1958; Zaika 1966; Gaevskaya et al., 1975). This paper is the first report of the trichodinid parasites on M. barbatus ponticus captured from the Black Sea waters, off Sinop, Turkey and provide information on the presence of trichodinid ectoparasites in relation to fish size, sex, and season.

\section{MATERIALS and METHODS}

Fish specimens were collected throughout a one-year period from commercial fishing vessels on Sinop coast of the Black Sea $\left(42^{\circ} 00^{\prime} 05^{\prime \prime} \mathrm{N}, 35^{\circ} 08^{\prime} 59^{\prime \prime} \mathrm{E}\right)$. In total, 330 fish specimens were sampled as monthly throughout a one-year period between June 2012 and July 2013 and investigated for trichodinid ectoparasites. At necropsy, the total lengths were measured and their sex was determined. During the investigation period, wet smears of gills, fins and skin were prepared and examined in order to detect the existence of trichodinids. Air-dried smears were stained with a $2 \%$ aqueous solution of silver nitrate for $10 \mathrm{~min}$, rinsed in distilled water, and exposed to ultraviolet light for 20 25 min (Lom and Dykova, 1992). Morphological diagnostic features of the adhesive disc and the denticle were identified under Olympus phase-contrast microscope at 100x magnification. The photomicrograhps of trichodinid specimens were taken with a light microscope equipped with a digital camera and drawings were made with camera lucida attachment. The measurements of adhesive disk and denticule elements were carried out as described by Van As and Basson (1989). All measurements are given in micrometers and based on 20 trichodinid specimens. Prevalence ( $\mathrm{P}$, $\%$ ) and mean intensity (MI) values of the trichodinids were determined according to Bush et al. (1997). The standard error (SE) of the mean intensity was calculated. The infestation values of three trichodinids were given for pooled data rather than by each trichodinid species. The normal distribution of the data was tested by using Kolmogorov-Simirnow test. While the differences in the mean intensity values of trichodinids for seasonal and fish size were tested by Kruskal-Wallis test (Nonparametric ANOVA), the difference between trichodinids loading on female and male fish was tested by the Mann-Whitney U-test. Some physicochemical parameters including water temperature $\left({ }^{\circ} \mathrm{C}\right)$, salinity (ppt), and $\mathrm{pH}$ values of sampling area were obtained from Sinop Meteorology General Directorate and the obtained data were pooled seasonally for each physicochemical parameter.

\section{RESULTS}

During the present study, three trichodinid species, T. domerguei Wallengren, 1897 (Figure 1A-2A), T. ovonucleata Raabe, 1958 (Figure 1B-2B) and P. obliqua Lom, 1963 (Figure 1C-2C) were identified 
on the gills of $M$. barbatus ponticus. The morphometrical data of the silver-impregnated specimens of all three species are submitted in Table 1.
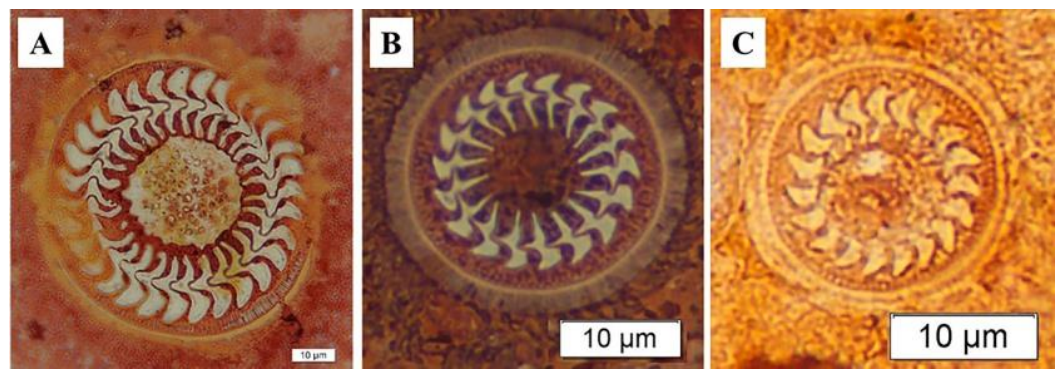

Figure 1. Photomicrographs of trichodinid ectoparasites identified on M. barbatus ponticus A. T. domerguei Wallengren, 1897; B. T. ovonucleata Raabe, 1958; C. P. obliqua Lom 1963. Specimens stained with silver-nitrate.

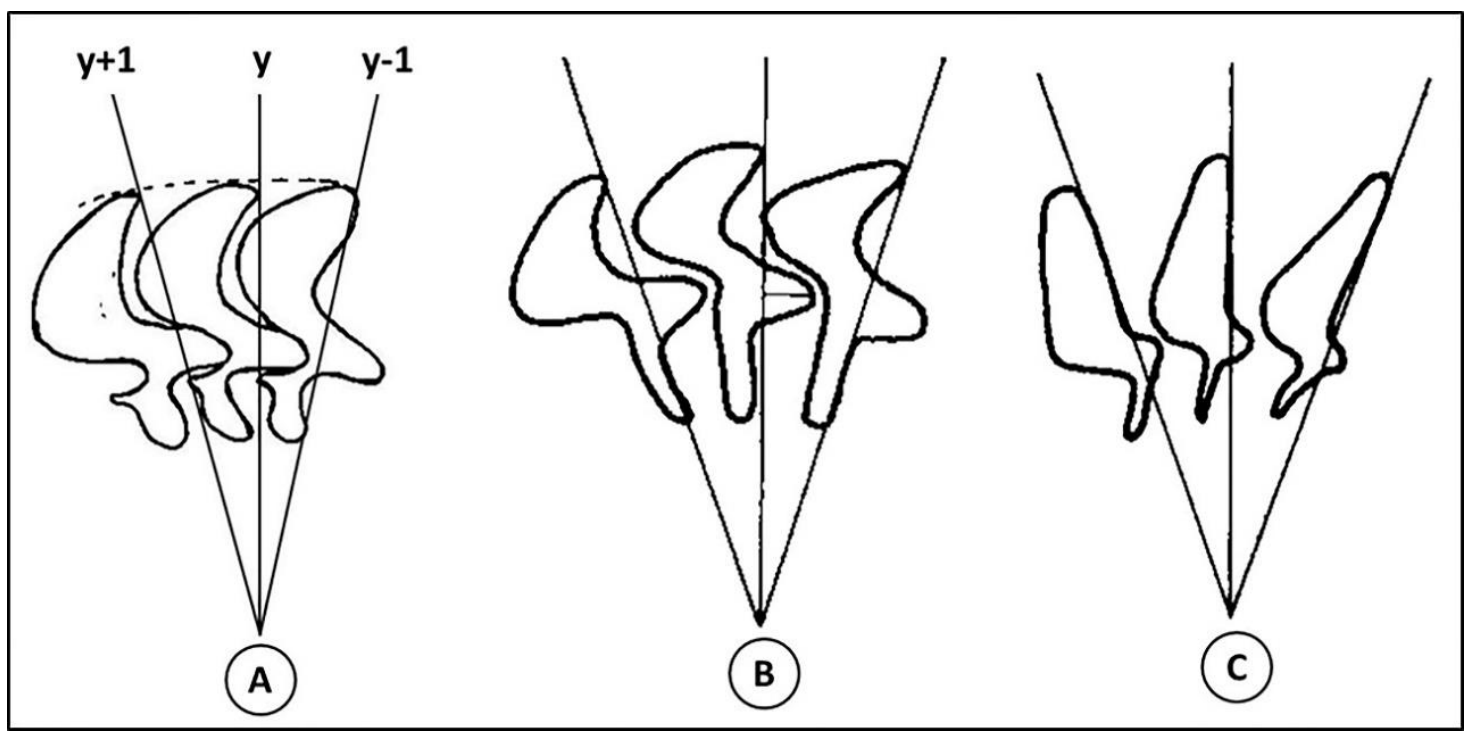

Figure 2. Diagrammatic drawings of the denticles of trichodinids identified in this study: A. T. domerguei, B. T. ovonucleata, C. P. obliqua.(y+1, y, y-1. Y axes).

Table 1. Morphometrical data of T. domerguei, T. ovonucleata and P. obliqua from M. barbatus ponticus (n: number of measured specimens) (range with arithmetic mean and standard error in parentheses) (all measurements in $\mu \mathrm{m})$.

\begin{tabular}{lccc}
\hline & $\begin{array}{c}\text { Trichodina } \\
\text { domerguei } \\
(\mathrm{n}: \text { 20) }\end{array}$ & $\begin{array}{c}\text { Trichodina } \\
\text { ovonucleata } \\
(\mathrm{n}: \text { 20) }\end{array}$ & $\begin{array}{c}\text { Paratrichodina } \\
\text { obliqua } \\
(\mathrm{n}: 20)\end{array}$ \\
\hline Body diameter & $71-80(76.2 \pm 1.4)$ & $24-32(29.5 \pm 1.9)$ & $18-20(19.5 \pm 0.4)$ \\
Adhesive dics diameter & $52-69(60.1 \pm 1.7)$ & $18-24(22.3 \pm 2.5)$ & $15-18(16.50 \pm 0.4)$ \\
Denticule ring diameter & $37-47(40.9 \pm 0.8)$ & $10-14(12.2 \pm 1.2)$ & $8-10(9.10 \pm 0.6)$ \\
Denticle number & $28-31$ & $18-20$ & $22-23$ \\
Number radial pins/denticle & $9-11$ & $5-6$ & 5 \\
Blade length & $6.0-8.0(7.1 \pm 0.3)$ & $1.5-2.5(2.0 \pm 0.22)$ & $3.0-3.5(3.25 \pm 0.4)$ \\
Ray length & $4.0-5.0(4.5 \pm 0.2)$ & $2.0-3.0(2.7 \pm 0.3)$ & $1.0-1.5(1.1 \pm 0.2)$ \\
Span of denticle & $15-18(17.5 \pm 0.5)$ & $4.0-6.0(5.0 \pm 0.6)$ & $4.0-4.8(4.3 \pm 0.20)$ \\
Central part width & $2.5-3.1(2.7 \pm 0.2)$ & $1.0-1.5(1.2 \pm 0.1)$ & $0.5-1.0(0.7 \pm 0.05)$ \\
Border membrane width & $4.5-5.0(4.7 \pm 0.2)$ & $1.5-2.5(2.0 \pm 0.3)$ & $1.4-2.0(1.9 \pm 0.08)$ \\
\hline
\end{tabular}

The prevalence and mean intensity values of $T$. domerguei, T. ovonucleata and $P$. obliqua were given as trichodinids for pooled data rather than by each trichodinid species. The proportion of trichodinids in stained slides were determined as 50: 40: 10 (T. ovonucleata: P. obliqua: $T$. domerguei) and T. ovonucleata was found commonly. Infestation incides of trichodinids infesting $M$. barbatus ponticus are reported in Table 2. 
Table 2. Combined infestation prevalence $(\%)$ and mean intensity levels of trichodinid ectoparasites (T. domerguei, $T$. ovonucleta and $P$. obliqua) on the $M$. barbatus ponticus (SE: Standard Error, n: Infected/Examined fish number)

\begin{tabular}{|c|c|c|c|c|}
\hline & $\begin{array}{c}\mathbf{n} \\
\text { (infec./exam.) }\end{array}$ & $\begin{array}{c}\text { Prevalence } \\
(\%)\end{array}$ & $\begin{array}{c}\text { Mean intensity } \\
\pm \text { S.E. }\end{array}$ & Statistical test used \\
\hline Seasons & & & & $\begin{array}{c}\text { Kruskal-Wallis } \\
\mathrm{P}<0.05\end{array}$ \\
\hline Winter & $25 / 90$ & 27.78 & $105.28 \pm 55.02^{\mathrm{a}}$ & \multirow{4}{*}{ Dunn's } \\
\hline Spring & $19 / 78$ & 24.36 & $123.21 \pm 90.61^{\mathrm{a}}$ & \\
\hline Summer & $0 / 82$ & 0.0 & $0.0^{\mathbf{b}}$ & \\
\hline Autumn & $0 / 80$ & 0.0 & $0.0^{\mathbf{b}}$ & \\
\hline $\begin{array}{l}\text { Length classes of } \\
\text { fish }(\mathrm{cm})\end{array}$ & & & & $\begin{array}{c}\text { Kruskal-Wallis } \\
\mathrm{P}>0.05 \\
\end{array}$ \\
\hline$<13$ & $7 / 60$ & 11.67 & $25.14 \pm 14.28$ & \\
\hline $13-15$ & $25 / 193$ & 12.95 & $94.64 \pm 68.21$ & \\
\hline$>15$ & $12 / 77$ & 15.58 & $202.58 \pm 112.41$ & \\
\hline Fish sex & & & & $\begin{array}{c}\text { Mann-Whitney } \\
\mathrm{P}>0.05\end{array}$ \\
\hline Female & $36 / 266$ & 13.53 & $126.25 \pm 60.13$ & \\
\hline Male & $8 / 64$ & 12.50 & $53.50 \pm 25.83$ & \\
\hline Overall & $44 / 330$ & 13.33 & $113.02 \pm 49.45$ & \\
\hline
\end{tabular}

The overall infestation prevalence $(\%)$ and mean intensity values recorded from 330 fish specimens were $13.33 \%$ and $113.02 \pm 49.45$ trichodinids per infested fish, respectively. Both infestation values were also recorded for seasons as well as the sex and length classes of the red mullet (Table 2). The maximum infestation prevalence and mean intensity values were recorded in winter and spring. No trichodinids were observed in summer and autumn. Statistically significant differences were determined in the seasonal mean intensity values and are showed in Table 2. Trichodinid ectoparasites were found in all size classes. The infection prevalence and intensities in larger fishes was detected higher than in small fishes (Table 2). However, no statistically significant differences were determined in relation to the fish size. Both infection prevalence and mean intensity values of trichodinids according to fish sex, in general, were found slightly lower in males but statistically significant difference wasn't determined $(\mathrm{P}>0.05)$ (Table 2$)$.

Some water physicochemical parameters was recorded monthly; while the highest water temperature values was in August $\left(26.6^{\circ} \mathrm{C}\right)$, it was the lowest in January $\left(8.3^{\circ} \mathrm{C}\right)$. During the study period, salinity varied from $15.55 \%$ to $18.01 \%$. The salinity was at its minimum in May $(15.55 \%$ o $)$ and maximum in August (18.01\%). Seasonal water parameters including temperature $\left({ }^{\circ} \mathrm{C}\right)$, salinity (ppt), and $\mathrm{pH}$ values are presented in Table 3.

Table 3. Seasonal water temperature $\left({ }^{\circ} \mathrm{C}\right)$, salinity $(\mathrm{ppt})$, and $\mathrm{pH}$ values in the sampling area

\begin{tabular}{lccc}
\hline Seasons & Temperature $\left({ }^{\circ} \mathbf{C}\right)$ & Salinity $(\mathbf{p p t})$ & pH \\
\hline Winter & 8.65 & 17.63 & 7.59 \\
Spring & 13.63 & 16.49 & 7.20 \\
Summer & 23.31 & 16.88 & 7.52 \\
Autumn & 17.70 & 17.82 & 7.81 \\
\hline
\end{tabular}

\section{DISCUSSION}

A total of 9 Trichodina species (including 7 species and 2 genus level) have been reported from the red mullet in the Black Sea, so far. These are T. gobii Raabe, 1959, T. jadranica Raabe, 1958, T. ovonucleata Raabe, 1958, T. inversa Dogiel, 1948, T. lepsii Lom, 1952, T. micromaculata Stein, 1975, T. rectuncinata Raabe, 1958, Trichodina sp1. (Gaevskaya et al., 1975) and Trichodina sp2. (Zaika, 1966). Trichodina ovonucleata has been reported from a variety of fish hosts in the Black Sea (Lom, 1963; 1970; Zaika, 1966; Gaevskaya et al., 1975; Grupcheva et al., 1989). Although T. ovonucleata has previously been reported from the red mullet in the Black Sea coast of Russia (Gaevskaya et al., 1975), this is the first record of this species in the Black Sea coast of Turkey. 
Paratrichodina obliqua was originally described by Lom (1963) from many fish species in the Black Sea. Since then, it has been reported from Trachurus mediterranneus ponticus Aleev, 1956, Ophidion rochei Muller, 1845, Atherina mochon pontica Eichwald, 1831 and Syngnathus typhle Linnaeus, 1758 in the Black Sea (Grupcheva et al., 1989) and Paralichthys olivaceus (Temminck \& Schlegel, 1846) in the Yellow Sea (Xu et al., 2001). This is the first record of P. obliqua occurring on the red mullet in Turkey and this also constitutes a new host record for P. obliqua. The results of the study reveal new records of the occurrence of $T$. ovonucleata and $P$. obliqua, in Turkey. Trichodina domerguei (Wallengren, 1897) is one of the most widely distributed trichodinid species and it has been reported from variety of fish hosts living in freshwater, brackish and marine habitats (Lom and Stein, 1966; Lom, 1970; Xu et al., 1999; Özer and Öztürk, 2015) but the present work confirms that it can also infest the red mullet.

Some investigators have reported that seasonal changes in the presence of trichodinids and their infestation indices are usually due to water temperature (Öğ̈̈t and Palm, 2005; Yemmen et al., 2010). The highest mean intensity levels in the present study were $123.21 \pm 90.61$ and $105.28 \pm 55.02$ trichodinids per infested fish in spring and winter respectively (Table 2). Various authors have reported that trichodinid infestation was the maximum level in spring and winter seasons (Öğ̈̈t and Palm, 2005; Yemmen et al., 2010). In this study, we noted that while no trichodinid recorded in summer and autumn season, the highest prevalence and mean intensity level of trichodinids are recorded in spring, which corresponds to the multiplication season for trichodinids (Table 2). Similarly, Majumder et al. (2015) determined a decrease in infection prevalence of trichodinids in the fishes in summer and autumn seasons similar to our data. This can probably happen because that the high temperatures of water detected in summer and autumn seasons (Table 3) prevents the proliferation of trichodinids. It seems that the average temperatures of water in spring and winter seasons favours the multiplication of three trichodinids identified in the present study. Thus, it can be stated that the high-level prevalence and mean intensities values of trichodinids observed in spring and winter seasons were probably due to the similar temperature needs of three trichodinid species in the present study. In other words, the presence of these trichodinids in both spring and winter seasons indicates that these species prefer low water temperatures $\left(8.65-13.63{ }^{\circ} \mathrm{C}\right)$.

Infestation prevalence (\%) and mean intensity values were found higher in the largest length class and female of fish. However, no statistically significant differences were determined in relation to the sex and size of fish as shown in Table 2. In other words, the size and sex of the red mullet were not factors affecting the number of trichodinids in the present study.

In conclusion, this paper is the first report on the trichodinid ectoparasite fauna of the red mullet, $M$. barbatus ponticus in Turkey. We report $T$. ovonucleata and $P$. obliqua to be new records for Turkish parasite fauna, and M. barbatus ponticus is also a new host record for $T$. domerguei and $P$. obliqua. Moreover, this study provides some new and valuable information on the presence of trichodinid parasites both related with host factors (host size and sex), and enviromental factors such as seasons and water temperature.

\section{REFERENCES}

Benedicto, J., Martínez-Gómez, C., \& Campillo, J. (2005). Induction of metallothioneins in Mullus barbatus as specific biomarker of metal contamination: A field study in the western Mediterranean. Ciencias Marinas, 31, 265-274. doi.org/10.7773/cm.v31i12.89

Bush, A.O., Lafferty, K.D., Lotz, J.M., \& Shostak, A.W. (1997). Parasitology meets ecology on its own terms: Margolis et al. revisited. The Journal of Parasitology, 83(4), 575-583.

Carreras-Aubets, M., Montero, F.E., Kostadinova, A., \& Carrasson, M. (2012). Parasite communities in the red mullet, Mullus barbatus L., respond to small-scale variation in the levels of polychlorinated biphenyls in the Western Mediterranean. Marine Pollution Bulletin, 64(9), 1853-1860. doi.org/10.1016/j.marpolbul.2012.06.008

Debenedetti, A.L., Madrid, E., \& Fuentes, M.V. (2013). Study of helminth parasites in the red mullet, Mullus barbatus, from the Mediterranean Sea and acquired in greater València, Spain. Revista IberoLatinoamericana de Parasitologia, 72(2), 118-123.

Essafi, K., Raibaut, A., \& Boudaoud-Krissat, K. (1983). Colobomatus steenstrupi (Richiardi, 1876) and Colobomatus mulli n. sp. (Copepoda: Philichthyidae), parasitic on fish of the genus Mullus (Mullidae) in the western Mediterranean. Systematic Parasitology, 5(2), 135-142. 
Gaevskaya, A.V, Gusev, A.V., Delyamure, S.L., Donets, Z.S., Iskova, N.I., Kornyushin, V.V., Kovaleva, A.A., Margaritov, N.M., Markevich, A.P., Mordvinova, T.N., Naidenova, N.N., Nikolaeva, V.M., Parukhin, A.M., Pogoreltseva, T.P, Smogorzhevskaya, L.A., Solonchenko, A.I., Stein, G.A., \& Shulman, S.S. (1975): Key to the parasites of vertebrata of the Black and Azov Seas. Naukova Dumka, Kiev, 552 pp.

Grupcheva, G., Lom, J., \& Dykova, I. (1989). Trichodinids (Ciliata: Urceolariidae) from gills of some marine fishes with the description of Trichodina zaika sp. n. Folia Parasitologica, 36, 193-207.

Hureau, J.C. (1986). Mullidae. Pp. 955-956. In: Whitehead, P.J., Bauchot, M.L., Hureau, J.C., Nielsen, J. \& Tortonese, E. (eds): Fishes of the North-Eastern Atlantic and the Mediterranean. - UNESCO, Paris.

Ivanova, P.P., Dobrovolov, I.S., \& Tsekov, A.G. (2014). Genetic Differentiation between Mullus barbatus from the Western Part of the Black Sea and Mullus surmuletus (Pisces, Mullidae) from the Mediterranean Sea. Ecologica Balcanica, 6, 37-44.

Keskin, E., \& Can, A. (2009). Phylogenetic relationships among four species and sub-species of Mullidae (Actinopterygii, Perciformes) based on mitochondrial cytochrome B, 12 rRNA and cytochrome oxidase II genes. Biochemical Systematics and Ecology, 37(5), 653-661. doi:10.1016/j.bse.2009.10.001

Lom, J. (1963). The ciliates of the family Urceolariidae inhabiting gills of fishes (the Trichodinella-group). Vestnik Ceskoslovenske Spolecnosti Zoologicke, 27, 7-19.

Lom, J. (1970). Trichodinid ciliates (Peritrichida: Urceolariidae) from some marine fishes. Folia Parasitologica, 17, 113-125.

Lom, J., \& Stein, G.A. (1966). Trichodinids from sticklebacks and remarks on the taxonomic position of Trichodina domerguei (Wall.). Vestnik Ceskoslovenske Spolecnosti Zoologicke, 30, 39-48.

Lom, J., \& Dykova, I. (1992). Protozoan parasites of fishes. - Elsevier Science Publishers, Amsterdam, 315 pp.

Majumder, S., Panda, S., \& Bandyopadhyay, P.K. (2015). Effect of temperature on the prevalence of different parasites in Cirrhinus mrigala Hamilton of West Bengal. Journal of Parasitic Disease, 39(1), 110-112. doi:10.1007/s12639-013-0295-4

Mathieu, A., Lemaire, P., Carriere, S., Drai, P., Giudicelli, J., \& Lafaurie, M. (1991). Seasonal and sex-linked variations in hepatic and extrahepatic biotransformation activities in striped mullet (Mullus barbatus). Ecotoxicology and Environmental Safety, 22(1), 45-57.

Ovcharenko, M.O., \& Yurahno, V.M. (2006). First Registration of Loma (Microsporidia, Glugeidae) Belonging Microsporidia in Black Sea Fish. Vestnik Zoologii, 40, 291-296.

Ögüt, H., \& Palm, H.W. (2005). Seasonal dynamics of Trichodina spp. on whiting (Merlangius merlangus) in relation to organic pollution on the eastern Black Sea coast of Turkey. Parasitology Research, 96(3), $149-153$.

Özer, A., \& Öztürk, T. (2015). Trichodinid fauna of freshwater fishes with infestation indices in the Lower Kizılırmak Delta in Turkey and a checklist of trichodinids (Ciliophora: Trichodinidae) in Turkish waters. Turkish Journal of Zoology, 39(5), 749-761.

Öztürk, T., \& Yeşil, A. (2018). Metazoan Parasite Fauna of the Red Mullet, Mullus barbatus ponticus Essipov, 1927 in the Sinop Coasts of the Black Sea. Turkish Journal of Fisheries and Aquatic Sciences, 18(1), $153-160$.

Raabe, Z. (1958). On some species of Trichodina (Ciliata - Peritricha) of gills of Adriatic fishes. Acta Parasitologica Polonica, 6, 355-361.

Turan, C. (2006). Phylogenetic relationships of Mediterranean Mullidae species (Perciformes) inferred from genetic and morphologic data. Scientia Marina, 70(2), 311-318.

TÜİK (2018). Turkish Statistical Institude web page. Fishery statistics https://tüik.gov.tr. Accessed at: 2018.11.20

Van As, J.G., \& Basson, L. (1989). Further contribution to the taxonomy of the Trichodinidae (Ciliophora: Peritrichida) and a review of the taxonomic status of some fish ectoparasitic trichodinids. Systematic Parasitology, 14, 157-179.

Vasileva, E.D. (2012). Morphological divergence of goatfishes (Genus Mullus, Mullidae, Perciformes) of the Black and Mediterranean Seas and the problem of assessment of their taxonomic relationships. Journal of Ichthyology, 52(8), 485-491.

Wang, Z., Zhou, T., \& Gu, Z. (2017). New data of two trichodinid ectoparasites (Ciliophora: Trichodinidae) from farmed freshwater fishes in Hubei, China. European Journal of Protistology, 60, 50-59.

Xu, K., Song, W., \& Warren, A. (1999). Trichodinid ectoparasites (Ciliophora: Peritrichida) from the gills of cultured marine fishes in China, with the description of Trichodinella lomi n. sp. Systematic Parasitology, 42(3), 219-227.

Xu, K., Song, W., Warren, A., \& Choi, J.K. (2001): Trichodinid ectoparasites (Ciliophora: Peritrichida) of some marine fishes from coastal regions of the Yellow Sea and Bohai Sea. Systematic Parasitology, 50(1), 69-79. 
Xu, K., Song, W., \& Warren, A. (2002). Taxonomy of trichodinids from the gills of marine fishes in coastal regions of the Yellow Sea, with descriptions of two new species of Trichodina Ehrenberg, 1830 (Protozoa: Ciliophora: Peritrichia). Systematic Parasitology, 51(2), 107-120.

Yemmen, C., Quilichini, Y., Katari, M.H., Marchand, B., \& Bahri, S. (2010). Morphological, ecological and histopathological studies of Trichodina gobii Raabe, 1959 (Ciliophora: Peritrichida) infecting the gills of Solea aegyptiaca. Protistology, 6(4), 258-263.

Zaika, V.E. (1966): On the fauna of protozoan parasites of fishes of the Black Sea. Pp. 13-31. In Vodianyts'kyi, V.O. (eds): Gelmintofauna Shivot Zhivot. Publishing House of Naukai Dumka, Kiev. 